九州大学学術情報リポジトリ

Kyushu University Institutional Repository

\title{
In Vitro Morphogenesis from Rhizomes of Cymbidium sinense
}

Huang, Chieh Li

Horticultural Science, National Chiayi University

Okubo, Hiroshi

https://doi.org/10.5109/4616

出版情報：九州大学大学院農学研究院紀要. 50 (1)，pp.11-18，2005-02-01. Faculty of Agriculture， Kyushu University

バージョン:

権利関係: 
J. Fac. Agr., Kyushu Univ., 50 (1), 11-18 (2005)

\title{
In Vitro Morphogenesis from Rhizomes of Cymbidium sinense
}

\author{
Chieh Li HUANG ${ }^{1 *}$ and Hiroshi OKUBO \\ Laboratory of Horticultural Science, Division of Agricultural Botany, \\ Department of Plant Resources, Faculty of Agriculture, \\ Kyushu University, Fukuoka 812-8581, Japan \\ (Received September 10, 2004 and accepted November 11, 2004)
}

\begin{abstract}
Effects of $\mathrm{N}^{6}$-benzyladenine (BA) and naphthyl acetic acid (NAA) and of nitrogen salt concentration in MS medium on in vitro morphogenesis from the rhizomes of Cymbidium sinense cv. Shue Pai Tsoa were investigated. Shoot formation was promoted with higher concentrations of BA irrespective of the presence of NAA. The plantlets with large number of leaves $(>5)$ were obtained with higher concentrations of both BA and NAA. Reduction of ammonium and potassium nitrate concentrations to $1 / 4$ or $1 / 2$ from the original concentrations enhanced shoot formation. The responsiveness to these treatments was suggested to be common in a wide range of terrestrial Cymbidium species.
\end{abstract}

\section{INTRODUCTION}

In vitro shoot formation from the rhizomes of terrestrial Cymbidium species with various concentrations and combinations of cytokinins and auxins in Murashige and Skoog (MS) medium (Murashige and Skoog, 1962) has been demonstrated in C. goeringii (Ueda and Torikata, 1969; Hasegawa, 1987), C. faberi (Hasegawa et al., 1985), C. kanran (Shimasaki and Uemoto, 1990), C. forrestii (Paek and Yeung, 1991) and C. ensifolium (Ogura and Okubo, 2003). Reduction of ammonium and potassium nitrate concentrations in MS medium from the original concentrations without an addition of any exogenous plant hormone was proved to be effective in promotion of shoot formation in C. kanran (Shimasaki and Uemoto, 1990; Ogura and Okubo, 2003) and C. ensifolium (Ogura and Okubo, 2003). Common effects of ethylene inhibitors to these species have also been reported. Shoot formation rate and number of shoots were increased from the rhizomes by silver thiosulfate (STS) and aminoethoxyvinyl glycine (AVG) in C. kanran (Shimasaki, 1992) and by $\mathrm{AgNO}_{3}$ in $C$. ensifolium (Ogura, 2003). The results suggest that the responsiveness is universal among terrestrial Cymbidium species.

Cymbidium sinese, another terrestrial Cymbidium species that grows in China, Hong Kong, Taiwan, northeast India, Myanmar, northern Thailand and Amami and Yakushima Islands, Japan, showed the similar response to $\mathrm{N}^{6}$-benzyladenine (BA) and naphthyl acetic acid (NAA) in shoot formation from the rhizomes to other terrestrial Cymbidium species as mentioned above, but it did not to the reduction of nitrogen salt concentrations (Ogura, 2003).

In this study, effects of cytokinin and auxin and of nitrogen salt concentration in MS medium on morphogenesis from the rhizomes of $C$. sinense were investigated in detail.

\footnotetext{
${ }^{1}$ Horticultural Science, National Chiayi University, 300 University Road, Chiayi, Taiwan

* Corresponding author (Fax: +866-5-271-7427)
} 


\section{MATERIALS AND METHODS}

\section{Plant materials and culture conditions}

Five $\mathrm{mm}$ long apices of the rhizomes of $C$. sinense cv. Shue Pai Tsoa were prepared aseptically from seed-derived and one or two year old plants and cultured in vitro in Horticultural Science, National Chiayi University, Chiyai, Taiwan. Well-grown and branched rhizomes were cut into $1.5 \mathrm{~cm}$ long segments and used for the experiments.

An MS medium supplemented with $30 \mathrm{gl}^{-1}$ sucrose and solidified with $2.7 \mathrm{gl}^{-1}$ Gelrite was used as a basal medium. The $\mathrm{pH}$ was adjusted to $5.5-5.7$ before adding the Gelrite, and the medium was autoclaved at $121^{\circ} \mathrm{C}$ for 15 minutes.

All cultures were incubated at $25 \pm 2^{\circ} \mathrm{C}$ in $16 \mathrm{~h}$ daylength $\left(28-36 \mu \mathrm{molsec}^{-1} \mathrm{~m}^{-2}\right)$.

\section{Effects of BA and NAA on morphogenesis}

The rhizome explants were cultured with various combinations of concentrations of $\mathrm{BA}$ and NAA. Ten explants were cultured in one $500 \mathrm{ml}$ culture bottle containing $70 \mathrm{ml}$ medium. Each treatment consisted of 50 explants with three replicates. Measurement took place after 90 days of culture on morphogenesis, and 150 days after culture on growth.

\section{Effects of ammonium and potassium nitrate concentrations in MS medium on morphogenesis}

The rhizome explants were cultured on the MS medium with various combinations and strength of ammonium nitrate and potassium nitrate (Table 1). Seven explants were

Table 1. Effects of BA and NAA on morphogenesis from rhizomes of Cymbidium sinense.

\begin{tabular}{|c|c|c|c|c|}
\hline \multicolumn{2}{|c|}{ Treatment $\left(\mathrm{mgl}^{-1}\right)$} & \multirow{2}{*}{$\begin{array}{c}\text { Number of } \\
\text { rhizomes }\end{array}$} & \multirow{2}{*}{$\begin{array}{c}\text { Number of } \\
\text { shoots }\end{array}$} & \multirow{2}{*}{$\begin{array}{l}\text { Browning } \\
\text { (\%) }\end{array}$} \\
\hline $\mathrm{BA}$ & NAA & & & \\
\hline 0 & 0 & $6.7 \mathrm{~d}^{*}$ & 0 & 0 \\
\hline 0 & 0.1 & $6.5 \mathrm{~d}$. & 0 & 7 \\
\hline 0 & 1.0 & $8.0 \mathrm{~b}$ & 0 & 13 \\
\hline 0 & 10 & $7.2 \mathrm{c}$ & 0 & 7 \\
\hline 0.1 & 0 & $3.7 \mathrm{f}$ & 0 & 0 \\
\hline 0.1 & 0.1 & $10.5 \mathrm{a}$ & 0 & 20 \\
\hline 0.1 & 1.0 & $3.2 \mathrm{~h}$ & 0 & 13 \\
\hline 0.1 & 10 & $4.7 \mathrm{e}$ & 0 & 7 \\
\hline 1.0 & 0 & $2.8 \mathrm{i}$ & $3.0 \mathrm{c}$ & 0 \\
\hline 1.0 & 0.1 & $3.5 \mathrm{~g}$ & $0.5 \mathrm{e}$ & 0 \\
\hline 1.0 & 1.0 & $8.2 \mathrm{~b}$ & $0.4 \mathrm{e}$ & 0 \\
\hline 1.0 & 10 & $4.0 \mathrm{e}$ & $0.5 \mathrm{e}$ & 0 \\
\hline 10 & 0 & $4.0 \mathrm{e}$ & $3.8 \mathrm{a}$ & 0 \\
\hline 10 & 0.1 & $0.2 \mathrm{k}$ & $3.2 \mathrm{bc}$ & 0 \\
\hline 10 & 1.0 & $1.3 \mathrm{k}$ & $3.3 \mathrm{~b}$ & 0 \\
\hline 10 & 10 & $2.0 \mathrm{j}$ & $2.3 \mathrm{~d}$ & 0 \\
\hline
\end{tabular}

Measured after 90 days of culture.

* Values followed by different letters are significantly different at $5 \%$ level. 
cultured in one $500 \mathrm{ml}$ culture bottle containing $70 \mathrm{ml}$ medium. Each treatment consisted of 21 explants with three replicates. Morphogenesis and plantlet sizes were recorded after 90 and 150 days of culture, respectively.

\section{RESULTS AND DISCUSSION}

\section{Effects of BA and NAA on morphogenesis}

Number of rhizomes 90 days after culture was more than four when the concentrations of NAA were the same as or higher than those of BA and when the treatments with $0.1 \mathrm{mgl}^{-1} \mathrm{BA}+1.0 \mathrm{mgl}^{-1} \mathrm{NAA}$ and $10 \mathrm{mgl}^{-1} \mathrm{BA}+10 \mathrm{mgl}^{-1} \mathrm{NAA}$ were given (Table 1, Fig. 1A). Among the treatments, the largest number of rhizomes was 10.5 with $0.1 \mathrm{mgl}^{-1} \mathrm{BA}+$ $0.1 \mathrm{mgl}^{-1} \mathrm{NAA}$, followed by 8.2 and 8.0 with $1.0 \mathrm{mgl}^{-1} \mathrm{BA}+1.0 \mathrm{mgl}^{-1} \mathrm{NAA}$ and $1.0 \mathrm{mgl}^{-1} \mathrm{NAA}$ only, respectively.
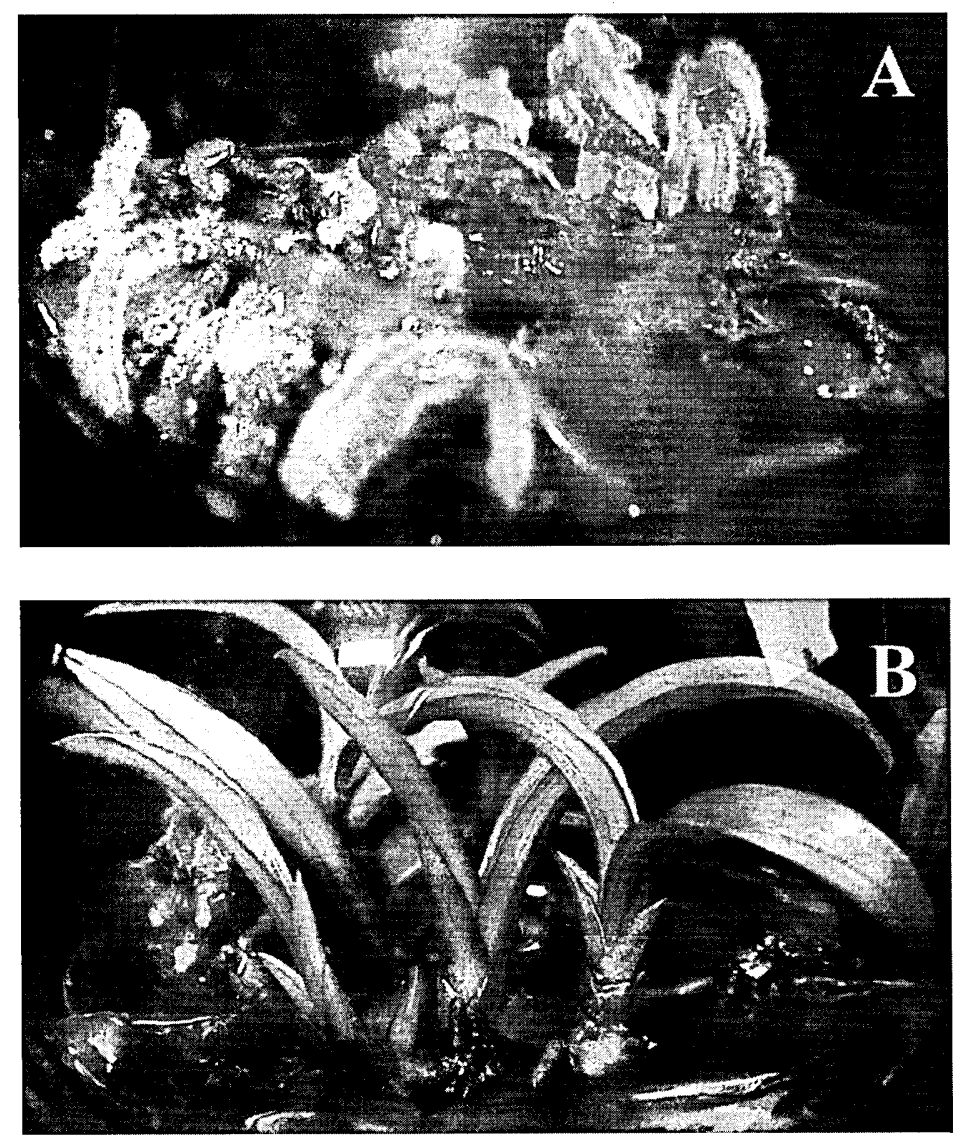

Fig. 1. Typical morphogenesis from rhizomes of Cymbidium sinense. (A); multiplication of rhizomes with BA $0.1 \mathrm{mgl}^{-1}+\mathrm{NAA} 0.1 \mathrm{mgl}^{-1}$,

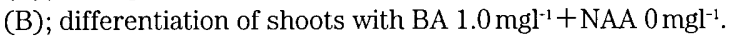


Shoot formation occurred when BA concentration was $1.0 \mathrm{mgl}^{-1}$ or above with or without NAA, among which $10 \mathrm{mgl}^{-1}$ BA only brought the largest number of shoots (3.8) (Table 1, Fig. 1B). No shoots were obtained with lower $\left(\leqq 0.1 \mathrm{mgl}^{-1}\right)$ BA irrespective of the NAA concentrations by 90 days of culture. No browning of the rhizomes was observed with higher BA concentrations $\left(\geqq 1.0 \mathrm{mgl}^{-1}\right)$.

The plantlets with large number of leaves $(>5)$, when counted 150 days of culture, were obtained with higher concentrations of both BA and NAA $\left(1.0 \mathrm{mgl}^{-1} \mathrm{BA}+1.0 \mathrm{mgl}^{-1}\right.$ $\mathrm{NAA}, 1.0 \mathrm{mgl}^{-1} \mathrm{BA}+10 \mathrm{mgl}^{-1} \mathrm{NAA}, 10 \mathrm{mgl}^{-1} \mathrm{BA}+10 \mathrm{mgl}^{-1} \mathrm{NAA}$ and $10 \mathrm{mgl}^{-1} \mathrm{BA}+1.0 \mathrm{mgl}^{-1}$ NAA) (Table 2). No roots developed without NAA. BA did not affect the length and number of roots.

The results in $C$. sinense in this study are in agreement with the previous reports on other terrestrial Cymbidium species (Ueda and Torikata, 1969; Hasegawa et al., 1985; Hasegawa, 1987; Shimasaki and Uemoto, 1990; Paek and Yeung, 1991; Ogura and Okubo, 2003). Response to cytokinins and auxins on in vitro shoot formation from rhizome explants seems to be general in terrestrial Cymbidium species.

Table 2. Effects of BA and NAA on growth of the cultures from rhizomes of Cymbidium sinense.

\begin{tabular}{|c|c|c|c|c|c|}
\hline \multirow{2}{*}{\multicolumn{2}{|c|}{ Treatment $\left(\mathrm{mgl}^{-1}\right)$}} & \multicolumn{2}{|c|}{ Shoot } & \multicolumn{2}{|c|}{ Root } \\
\hline & & \multirow{2}{*}{$\begin{array}{l}\text { Leaf length } \\
(\mathrm{cm})\end{array}$} & \multirow{2}{*}{$\begin{array}{c}\text { Number of } \\
\text { leaves }\end{array}$} & \multirow{2}{*}{$\begin{array}{c}\text { Length } \\
(\mathrm{cm})\end{array}$} & \multirow{2}{*}{ Number } \\
\hline $\mathrm{BA}$ & NAA & & & & \\
\hline 0 & 0 & 0 & 0 & 0 & 0 \\
\hline 0 & 0.1 & 0 & 0 & 0 & 0 \\
\hline 0 & 1.0 & 0 & 0 & 0 & 0 \\
\hline 0 & 10 & 2.8 def* $^{*}$ & $2.8 \mathrm{~d}$ & $1.4 \mathrm{bc}$ & $1.5 \mathrm{~b}$ \\
\hline 0.1 & 0 & $2.4 \mathrm{ef}$ & $2.9 \mathrm{~d}$ & 0 & 0 \\
\hline 0.1 & 0.1 & $6.5 \mathrm{a}$ & $4.0 \mathrm{bc}$ & $2.4 \mathrm{ab}$ & $2.3 \mathrm{a}$ \\
\hline 0.1 & 1.0 & $4.3 \mathrm{bc}$ & $3.9 \mathrm{bc}$ & $2.5 \mathrm{ab}$ & $2.1 \mathrm{a}$ \\
\hline 0.1 & 10 & 3.3 cde & $3.6 \mathrm{bcd}$ & $3.5 \mathrm{a}$ & $2.3 \mathrm{a}$ \\
\hline 1.0 & 0 & $1.5 \mathrm{fg}$ & $4.1 \mathrm{bc}$ & 0 & 0 \\
\hline 1.0 & 0.1 & $2.1 \mathrm{f}$ & $4.3 \mathrm{~b}$ & $0.9 \mathrm{bc}$ & $1.3 \mathrm{~b}$ \\
\hline 1.0 & 1.0 & $4.6 \mathrm{~b}$ & $5.8 \mathrm{a}$ & $1.6 \mathrm{ab}$ & $2.2 \mathrm{a}$ \\
\hline 1.0 & 10 & $3.6 \mathrm{~cd}$ & $5.7 \mathrm{a}$ & $0.7 \mathrm{c}$ & $1.9 \mathrm{ab}$ \\
\hline 10 & 0 & $1.4 \mathrm{~g}$ & $4.2 \mathrm{bc}$ & 0 & 0 \\
\hline 10 & 0.1 & $2.4 \mathrm{ef}$ & $3.5 \mathrm{~cd}$ & $0.8 \mathrm{bc}$ & $1.3 \mathrm{~b}$ \\
\hline 10 & 1.0 & $3.5 \mathrm{~cd}$ & $5.1 \mathrm{a}$ & $1.2 \mathrm{bc}$ & $1.4 \mathrm{~b}$ \\
\hline 10 & 10 & $2.0 \mathrm{f}$ & $5.6 \mathrm{a}$ & $2.2 \mathrm{ab}$ & $1.7 \mathrm{ab}$ \\
\hline
\end{tabular}

Measured after 150 days of culture.

* Values followed by different letters are significantly different at $5 \%$ level.

\section{Effects of ammonium and potassium nitrate concentrations in MS medium on morphogenseis}

Reduction of ammonium and potassium nitrate strengths to $1 / 4$ and $1 / 4,1 / 4$ and $1 / 2$, and $1 / 2$ and $1 / 4$, respectively from the original concentrations brought $100 \%$ shoot forma- 
tion after 90 days of culture (Table 3 ). The highest number of shoots obtained was 3.4 with $1 / 4$ ammonium and $1 / 4$ potassium nitrates, followed by 3.3 with $1 / 4$ ammonium and $1 / 2$ potassium nitrates. Half strength of ammonium nitrate also gave the higher number of shoots, 2.9 and 2.7, with $1 / 4$ and $1 / 2$ potassium nitrate, respectively. Number of rhizomes was not affected by the reduction of the concentrations.

Table 3. Effects of reduction of ammonium nitrate and potassium nitrate in MS medium on morphogenesis from rhizomes of Cymbidium sinense.

\begin{tabular}{|c|c|c|c|c|c|}
\hline \multirow{2}{*}{\multicolumn{2}{|c|}{$\begin{array}{l}\text { Strength of } \\
\text { nitrogen salts in } \\
\text { MS media }\end{array}$}} & \multirow{3}{*}{$\begin{array}{l}\% \text { of shoot } \\
\text { formation }\end{array}$} & \multicolumn{2}{|c|}{ Number } & \multirow{3}{*}{$\begin{array}{l}\text { Browning } \\
\text { of rhizome } \\
\text { (\%) }\end{array}$} \\
\hline & & & \multirow{2}{*}{ Rhizome } & \multirow{2}{*}{ Shoot } & \\
\hline $\mathrm{NH}_{4} \mathrm{NO}_{3}$ & $\mathrm{KNO}_{3}$ & & & & \\
\hline 0 & 0 & 87 & $2.1 \mathrm{o}^{*}$ & $2.5 \mathrm{bc}$ & 7 \\
\hline 0 & $1 / 8$ & 47 & $1.5 \mathrm{p}$ & $0.2 \mathrm{~d}$ & 20 \\
\hline 0 & $1 / 4$ & 0 & $5.7 \mathrm{c}$ & 0 & 7 \\
\hline 0 & $1 / 2$ & 0 & $3.0 \mathrm{~lm}$ & 0 & 0 \\
\hline 0 & 1 & 40 & $3.6 \mathrm{ij}$ & $0.2 \mathrm{~d}$ & 7 \\
\hline 0 & 2 & 47 & $2.9 \mathrm{lmn}$ & $0.2 \mathrm{~d}$ & 7 \\
\hline $1 / 8$ & 0 & 40 & $1.6 \mathrm{p}$ & $0.2 \mathrm{~d}$ & 7 \\
\hline $1 / 8$ & $1 / 8$ & 0 & $3.6 \mathrm{ij}$ & 0 & 7 \\
\hline $1 / 8$ & $1 / 4$ & 0 & $4.3 \mathrm{~g}$ & 0 & 13 \\
\hline $1 / 8$ & $1 / 2$ & 0 & $1.4 \mathrm{p}$ & 0 & 28 \\
\hline $1 / 8$ & 1 & 0 & $3.4 \mathrm{jk}$ & 0 & 20 \\
\hline $1 / 8$ & 2 & 0 & $1.4 \mathrm{p}$ & 0 & 20 \\
\hline $1 / 4$ & 0 & 0 & $5.0 \mathrm{gh}$ & 0 & 0 \\
\hline $1 / 4$ & $1 / 8$ & 40 & $5.0 \mathrm{gh}$ & $0.3 \mathrm{~d}$ & 0 \\
\hline $1 / 4$ & $1 / 4$ & 100 & $3.0 \mathrm{~lm}$ & $3.4 \mathrm{a}$ & 0 \\
\hline $1 / 4$ & $1 / 2$ & 100 & $5.6 \mathrm{~cd}$ & $3.3 \mathrm{a}$ & 0 \\
\hline $1 / 4$ & 1 & 0 & $6.6 \mathrm{~b}$ & 0 & 0 \\
\hline $1 / 4$ & 2 & 0 & $3.5 \mathrm{j}$ & 0 & 0 \\
\hline $1 / 2$ & 0 & 47 & $4.1 \mathrm{gh}$ & $0.3 \mathrm{~d}$ & 13 \\
\hline $1 / 2$ & $1 / 8$ & 0 & $4.3 \mathrm{~g}$ & 0 & 13 \\
\hline $1 / 2$ & $1 / 4$ & 100 & $1.7 \mathrm{p}$ & $2.9 \mathrm{ab}$ & 0 \\
\hline $1 / 2$ & $1 / 2$ & 80 & $2.8 \mathrm{mn}$ & $2.7 \mathrm{abc}$ & 20 \\
\hline $1 / 2$ & 1 & 0 & $6.6 \mathrm{~b}$ & 0 & 13 \\
\hline $1 / 2$ & 2 & 33 & $12.5 \mathrm{a}$ & $0.2 \mathrm{~d}$ & 0 \\
\hline 1 & 0 & 40 & $1.7 \mathrm{p}$ & $0.2 \mathrm{~d}$ & 28 \\
\hline 1 & $1 / 8$ & 53 & $2.6 n$ & $0.3 \mathrm{~d}$ & 13 \\
\hline 1 & $1 / 4$ & 47 & $4.9 \mathrm{f}$ & $0.2 \mathrm{~d}$ & 13 \\
\hline 1 & $1 / 2$ & 53 & $2.7 \mathrm{n}$ & $0.3 \mathrm{~d}$ & 7 \\
\hline 1 & 1 & 73 & $4.9 \mathrm{f}$ & $1.8 \mathrm{c}$ & 13 \\
\hline 1 & 2 & 20 & $0.8 \mathrm{q}$ & $0.2 \mathrm{~d}$ & 48 \\
\hline 2 & 0 & 0 & $5.3 \mathrm{de}$ & 0 & 13 \\
\hline 2 & $1 / 8$ & 40 & $3.9 \mathrm{hi}$ & $0.2 \mathrm{~d}$ & 7 \\
\hline 2 & $1 / 4$ & 40 & $2.6 n$ & $0.2 \mathrm{~d}$ & 7 \\
\hline 2 & $1 / 2$ & 0 & $3.5 \mathrm{j}$ & 0 & 20 \\
\hline 2 & 1 & 40 & $4.0 \mathrm{gh}$ & $0.2 \mathrm{~d}$ & 13 \\
\hline 2 & 2 & 0 & $3.2 \mathrm{kl}$ & 0 & 13 \\
\hline
\end{tabular}

Measured after 90 days of culture.

* Values followed by different letters are significantly different at $5 \%$ level. 
Number of leaves was not so much affected by the reduction, but among the treatments, combination of $1 / 2$ strength of ammonium nitrate and $1 / 4$ strength of potassium nitrate produced the plantlets having longest leaf $(6.3 \mathrm{~cm})$ and the largest number of leaves (4.5), 150 days after culture (Table 4). The weaker the ammonium nitrate strength ( $1 / 2$ to 0$)$ was, the longer the roots were. The higher the potassium nitrate con-

Table 4. Effects of reduction of ammonium nitrate and potassium nitrate in MS mdedium on growth of the cultures from rhizomes of Cymbidium sinense.

\begin{tabular}{|c|c|c|c|c|c|c|}
\hline \multirow{2}{*}{\multicolumn{2}{|c|}{$\begin{array}{l}\text { Strength of } \\
\text { nitrogen salts in } \\
\text { MS media }\end{array}$}} & & \multicolumn{2}{|c|}{ Shoot } & \multicolumn{2}{|c|}{ Root } \\
\hline & & & \multirow{2}{*}{$\begin{array}{l}\text { Leaf length } \\
\text { (cm) }\end{array}$} & \multirow{2}{*}{$\begin{array}{c}\text { Number of } \\
\text { leaves }\end{array}$} & \multirow{2}{*}{$\begin{array}{l}\text { Length } \\
(\mathrm{cm})\end{array}$} & \multirow{2}{*}{ Number } \\
\hline $\mathrm{NH}_{4} \mathrm{NO}_{3}$ & $\mathrm{KNO}_{1}$ & & & & & \\
\hline 0 & 0 & & $2.1 \mathrm{j}^{*}$ & $2.9 \mathrm{~h}$ & $4.4 \mathrm{~cd}$ & $1.0 \mathrm{o}$ \\
\hline 0 & $1 / 8$ & & $1.6 \mathrm{j}$ & $2.9 \mathrm{~h}$ & $5.3 \mathrm{ab}$ & 1.00 \\
\hline 0 & $1 / 4$ & & $4.6 \mathrm{hi}$ & $4.1 \mathrm{bcd}$ & $5.8 \mathrm{a}$ & $1.9 \mathrm{klmn}$ \\
\hline 0 & $1 / 2$ & & $4.5 \mathrm{i}$ & $3.8 \mathrm{def}$ & $4.8 \mathrm{bc}$ & $1.8 \mathrm{lmn}$ \\
\hline 0 & 1 & & 5.0 defghi & 3.9 cdef & $4.8 \mathrm{bc}$ & $2.2 \mathrm{jjklmn}$ \\
\hline 0 & 2 & & 5.2 cdefghi & 4.0 bcde & $4.5 \mathrm{c}$ & $2.9 \mathrm{efgh}$ \\
\hline $1 / 8$ & 0 & & 5.2 cdefghi & 4.0 bcde & 2.0 hijklmn & 2.4 ghijkl \\
\hline $1 / 8$ & $1 / 8$ & & 5.2 cdefghi & 3.7 efg & $2.7 \mathrm{efg}$ & 2.3 hijklm \\
\hline $1 / 8$ & $1 / 4$ & & 5.2 cdefghi & 4.0 bcde & 2.3 ghijk & $1.6 \mathrm{no}$ \\
\hline $1 / 8$ & $1 / 2$ & & 4.9 efghi & 4.0 bcde & $2.9 \mathrm{ef}$ & $2.2 \mathrm{jjklmn}$ \\
\hline $1 / 8$ & 1 & & 5.6 abcdefg & 4.0 bcde & $3.8 \mathrm{~d}$ & 2.6 ghij \\
\hline $1 / 8$ & 2 & & $4.6 \mathrm{hi}$ & $3.8 \mathrm{def}$ & $3.1 \mathrm{e}$ & $2.1 \mathrm{jklmn}$ \\
\hline $1 / 4$ & 0 & & 5.2 cdefghi & 4.0 bcde & $1.5 \mathrm{mno}$ & 2.7 fghij \\
\hline $1 / 4$ & $1 / 8$ & & 5.0 defghi & $3.7 \mathrm{efg}$ & 1.6 klmno & 2.7 fghij \\
\hline $1 / 4$ & $1 / 4$ & & 5.3 bcdefgh & 4.0 bcde & 1.4 no & $2.9 \mathrm{efgh}$ \\
\hline $1 / 4$ & $1 / 2$ & & $6.1 \mathrm{ab}$ & $4.1 \mathrm{bcd}$ & 2.0 hijklmn & $3.3 \mathrm{cdef}$ \\
\hline $1 / 4$ & 1 & & $5.9 \mathrm{abc}$ & $4.3 \mathrm{ab}$ & 2.0 hijklmn & $3.8 \mathrm{abc}$ \\
\hline $1 / 4$ & 2 & & $4.9 \mathrm{fghi}$ & $3.9 \mathrm{cdef}$ & 2.1 ghijkl & 3.0 defg \\
\hline $1 / 2$ & 0 & & $5.8 \mathrm{abcd}$ & $4.0 \mathrm{bcd}$ & 1.6 Imno & $3.7 \mathrm{abc}$ \\
\hline $1 / 2$ & $1 / 8$ & & 5.7 abcde & $4.3 \mathrm{ab}$ & 1.7 klmno & $3.7 \mathrm{abc}$ \\
\hline $1 / 2$ & $1 / 4$ & & $6.3 \mathrm{a}$ & $4.5 \mathrm{a}$ & $1.8 \mathrm{mno}$ & $4.1 \mathrm{ab}$ \\
\hline $1 / 2$ & $1 / 2$ & & $6.1 \mathrm{ab}$ & $4.2 \mathrm{abc}$ & $1.9 \mathrm{ijklmn}$ & 3.5 bcde \\
\hline $1 / 2$ & . & & $5.9 \mathrm{abc}$ & $4.5 \mathrm{a}$ & 2.4 ghij & $4.2 \mathrm{a}$ \\
\hline $1 / 2$ & 2 & & 5.6 abcdef & $4.2 \mathrm{abc}$ & $1.9 \mathrm{ijklmn}$ & $3.6 \mathrm{abcd}$ \\
\hline 1 & 0 & & 5.0 defghi & 4.0 bcde & $1.8 \mathrm{jklmno}$ & 2.5 ghijk \\
\hline 1 & $1 / 8$ & & $5.3 \mathrm{bcdefgh}$ & 4.0 bcde & $3.0 \mathrm{ef}$ & 3.0 defg \\
\hline 1 & $1 / 4$ & & 5.5 bcdefg & $3.7 \mathrm{efg}$ & 2.1 ghijklm & $2.9 \mathrm{efgh}$ \\
\hline 1 & $1 / 2$ & & $4.6 \mathrm{hi}$ & 3.9 cdef & 1.8 klmno & $1.7 \mathrm{mn}$ \\
\hline 1 & 1 & & 5.0 defghi & $3.6 \mathrm{fg}$ & 2.5 efghi & $2.1 \mathrm{jklmn}$ \\
\hline 1 & $\therefore$ & & $4.5 \mathrm{hi}$ & $3.4 \mathrm{~g}$ & $2.6 \mathrm{efgh}$ & 2.4 ghijkl \\
\hline 2 & 0 & & $4.8 \mathrm{fghi}$ & $3.4 \mathrm{~g}$ & $1.2 \mathrm{o}$ & 1.6 no \\
\hline 2 & $1 / 8$ & & 5.1 cdefghi & 3.9 cdef & 2.0 hijkimn & 2.5 ghijk \\
\hline 2 & $1 / 4$ & & $4.7 \mathrm{ghi}$ & 3.7 efg & $1.5 \mathrm{mno}$ & 2.5 ghijk \\
\hline 2 & $1 / 2$ & & 5.0 defghi & 3.8 def & $1.8 \mathrm{jklmn}$ & 2.5 ghijk \\
\hline 2 & 1 & & 5.0 dèfghi & 3.9 cdef & 2.0 hijklmn & $2.8 \mathrm{fghi}$ \\
\hline 2 & 2 & & 4.9 fghi & $3.6 \mathrm{fg}$ & $1.5 \mathrm{mno}$ & 2.3 hijklm \\
\hline
\end{tabular}

Measured after 150 days of culture.

* Values followed by different letters are significantly different at $5 \%$ level. 
centrations within the same ammonium nitrate concentrations, the longer the roots were. The antagonism of the two nitrogen salts is suggested in root growth. Ammonium ions were found to dramatically inhibit Arabidopsis thaliana seedling root growth in the absence of potassium, and this inhibition could be reversed by including in the growth medium low levels of potassium (Cao et al., 1993).

It is clarified that $C$. sinense shows the similar response not only to the manipulation with BA and NAA but also with the reduction of nitrate salt concentrations of MS medium to other Cymbidium species. No promotional effect on shoot formation was, however, reported previously in $C$. sinense by the reduction of ammonium and potassium nitrate concentrations (Ogura, 2003). One possible reason of the difference in the results between two experiments may be due to the difference of the explant sources and ages. Due to long history of cultivation and cultivar development in different places in this species, there may be wide variation in physiological as well as in morphological characters. Difference by the ages of the rhizomes and seasonal changes in responsiveness to the treatments may exist. Another possibility is the positions and length of the explants used. Only the rhizome apices were used and the length was $0.5 \mathrm{~cm}$ in Ogura's experiment (Ogura, 2003), whereas all the positions of the rhizomes of $1.5 \mathrm{~cm}$ in length, including apices, were used here.

Cymbidium sinense is one of the most southern terrestrial species among other terrestrial Cymbidium species such as $C$. goeringii, C. faberi, C. kanran, C. forrestii and C. ensifolium, and less tolerant to low temperature. It means that $C$. sinense has weaker dormancy than others, and it is more sensitive to the treatments. This may be the reason that the shoot formation was observed without auxin and cytokinin and without the reduction of nitrate salt strength (Tables 3 and 4), although no shoots were formed in the first experiment of this study (Tables 1 and 2).

It is concluded that the responsiveness to the plant hormones and nitrate salt concentration is universal among terrestrial Cymbidium species.

Ogura (2003) showed the additive effects of the combined treatment with reduction of nitrate salt concentrations and with $1 \mathrm{mgl}^{-1} \mathrm{BA}+0.1 \mathrm{mgl}^{-1} \mathrm{NAA}$ on shoot formation rate and number of shoots in $C$. kanran. The treatment may be applicable to $C$. sinense. Addition of AVG together with the reduction treatment of nitrate salts also gave an excellent number of shoots in $C$. kanran, although the response to $\mathrm{AgNO}_{: 3}$ was weak (Ogura, 2003). It should be also taken into consideration in rhizome culture of $C$. sinense.

\section{REFERENCES}

Cao, Y., A. D. M. Glass and N. M. Crawford 1993 Ammonium inhibition of Arabidopsis root growth can be reversed by potassium and by auxin resistance mutations aux1, axr1, and axr2. Plant Physiol., 102: $983-989$

Hasegawa, A. 1987 Studies on the propagation of oriental Cymbidium. Mem. Fac. Agr. Kagawa Univ., 50: $1-108$

Hasegawa, A., H. Ohashi and M. Goi 1985 Effects of BA, rhizome length, mechanical treatment and liquid shaking culture on the shoot formation from rhizome in Cymbidium faberi Rolfe. Acta Hortic., 166: $25-40$

Murashige, T. and F. Skoog 1962 A revised medium for rapid growth and bioassays with tobacco tissue cultures. Physiol. Plant., 15: 473-497

Ogura, Y. 2003 Studies on in vitro organogenesis in Cymbidium species. Ph. D. Thesis, Kyushu 
University, Fukuoka, Japan

Ogura, Y. and H. Okubo 2003 In vitro shoot formation from rhizome apices of Cymbidium ensifolium and C. kanran. J. Fac. Agr., Kyushu Univ., 47: 301-306

Paek, K. Y. and E. C. Yeung 1991 The effects of 1-naphthaleneacetic acid and $\mathrm{N}^{\mathrm{i}}$-benzyladenine on the growth of Cymbidium forrestii rhizomes in vitro. Plant Cell, Tiss. Org. Cult., 24: 65-71

Shimasaki, K. 1992 The role of ethylene in the plantlet formation of Cymbidium kanran from rhizome culture. Plant Tiss. Cult. Letters., 9: 202-205

Shimasaki, K. and S. Uemoto 1990 Micropropagation of a terrestrial Cymbidium species using rhizomes developed from seeds and pseudobulbs. Plant Cell, Tiss. Org. Cult., 22: 237-244

Ueda, H. and H. Torikata 1969 Organogenesis in the meristem cultures of cymbidiums. II. Effects of growth substances on the organogenesis in dark culture. J. Japan. Soc. Hort. Sci., 38: 78-83 